\title{
Rootstocks and planting types on root architecture and vegetative vigor of 'Pera' sweet orange trees
}

\author{
Thaís N. Meneses ${ }^{1}$, Mauricio A. Coelho Filho², Hermes P. Santos Filho², Luana L. de A. dos Santos \\ Abelmon da S. Gesteira² \& Walter dos S. Soares Filho ${ }^{2}$
}

\begin{abstract}
${ }^{1}$ Universidade Federal do Recôncavo da Bahia/Centro de Ciências Agrárias, Ambientais e Biológicas/Pós-Graduação em Engenharia Agrícola. Cruz das Almas, BA, Brasil. E-mail: th41s.nascimento@gmail.com - ORCID: 0000-0001-7337-0115

${ }^{2}$ Embrapa Mandioca e Fruticultura. Cruz das Almas, BA, Brasil. E-mail: mauricio-antonio.coelho@embrapa.br (Corresponding author) - ORCID: 0000-0002-46675535; hermes.santos@embrapa.br - ORCID: 0000-0002-5144-3974; abelmon.gesteira@embrapa.br - ORCID: 0000-0002-7590-0455; walter.soares@embrapa.br - ORCID: 0000-0001-5410-3740

${ }^{3}$ Universidade Federal do Recôncavo da Bahia/Centro de Ciências Agrárias, Ambientais e Biológicas. Cruz das Almas, BA, Brasil. E-mail: luanalaais@gmail.com ORCID: 0000-0002-0239-7094
\end{abstract}

\begin{abstract}
Root architecture affects plant growth and agricultural productions. Although it is related to genetic factors, soil physical limitations can affect the root system and volume of explored soil, compromising plant growth and fruit production. Considering the need to mitigate these restrictions, the objective of the present study was to evaluate two planting types (planting of protected seedlings and planting of seeds in definitive place) and two scion-rootstock combinations ('Pera' sweet orange, CNPMF D-6 selection, combined with 'Santa Cruz Rangpur' lime and 'Sunki Tropical' mandarin rootstocks). The experiment was conducted at the Lagoa do Coco Farm, Rio Real, BA, Brazil, in a Oxisol under rainfed conditions. Biometric, physiological, and soil water content evaluations were made during the experiment. Soil mechanical resistance to root penetration and root system characteristics were also evaluated. Roots were concentrated on the soil surface layers $(0-0.40 \mathrm{~m})$, extending horizontally up to $1.50 \mathrm{~m}$ from the plant, regardless of the management practices used. The total root length in each root diameter classes studied, root length density, and total root mean diameter were higher for planting of protected seedling, resulting in greater root development. Plants from 'Pera' sweet orange scion grafted on 'Santa Cruz Rangpur' lime rootstock had earlier production and were more vigorous. Soil structure affects root growth, and the root distribution up to $0.40 \mathrm{~m}$ depth is correlated with plant vigor, yield, and water status under rainfed conditions.
\end{abstract}

Key words: citriculture, root, cohesive soil, drought tolerance

\section{Arquitetura radicular e vigor vegetativo da laranjeira 'Pera' sobre diferentes porta-enxertos e tipos de plantios}

RESUMO: A arquitetura radicular afeta o crescimento da planta e a sua produção agrícola. Embora esteja relacionada a fatores genéticos, limitações hídricas e físicas do solo podem reduzir o volume do sistema radicular e do solo explorado, comprometendo, assim, o desenvolvimento vegetal e produtivo. Para mitigar essas restrições foram adotados dois tipos de plantio (plantio de mudas protegidas e plantio de sementes no local definitivo) e duas combinações copa/porta-enxerto: laranjeira 'Pera', seleção CNPMF-D6, enxertada em limoeiro ‘Cravo Santa Cruz' e em tangerineira ‘Sunki Tropical. O experimento foi conduzido na Fazenda Lagoa do Coco, Rio Real, BA, em um Oxisol e condição de sequeiro. Foram realizadas medidas biométricas, fisiológicas e umidade do solo ao longo do experimento. Também foram avaliadas a resistência do solo à penetração mecânica e várias características do sistema radicular. Independente das práticas de manejo adotadas, as raízes se concentraram na superfície, nos primeiros $0,40 \mathrm{~m}$ do solo, estendendo-se horizontalmente até $1,5 \mathrm{~m}$ da planta. O comprimento total de raiz em todas as classes de diâmetro estudadas, a densidade do comprimento de raiz e o diâmetro médio de raiz, foram superiores para o plantio de muda, resultando em maior desenvolvimento radicular das plantas. As plantas de laranjeira 'Pera' sobre o limoeiro 'Cravo Santa Cruz' foram mais precocemente produtivas e vigorosas. A estrutura do solo exerce influência sobre o crescimento radicular, sendo que a distribuição a $0,4 \mathrm{~m}$ de profundidade é um melhor indicador do vigor, produtividade e status hídrico da planta, cultivada em condições de sequeiro.

Palavras-chave: citricultura, raiz, solos coesos, tolerância à seca 


\section{INTRODUCTION}

Citriculture has socioeconomic importance to the Coastal Tablelands region, in the Northeast of Brazil, where Bahia and Sergipe are the third and fourth largest citrus producing states, respectively. Citrus crops cover approximately 87,782 hectares in this geomorphological region, which is responsible for $6.2 \%$ of the citrus production in Brazil (IBGE, 2017).

The soil compaction and irregular rainfall distribution are constant challenges for the citriculture in the Coastal Tablelands region, considering the predominant rainfed production; they directly affect the plant yield and fruit quality, and decrease useful life of plants, contributing to the vulnerability of citrus orchards (Cintra, 2011; Rezende et al., 2015).

The planting seeds of citrus rootstocks directly in their definitive place has been adopted by citrus growers as an alternative management to mitigate restrictions imposed by cohesive layers of the soil. The hypothesis is that the successive pruning of roots in the transplants (seed germination container-nursery-definitive place) in conventional planting reduces the dominance of the main root, and alters the plant morphology and physiology, compromising its development and acclimatization, in detriment of precocity and yield (Rezende, 2013; Rezende et al., 2015).

The predominance of the use of one or few rootstocks makes the brazilian citrus industry vulnerable to biotic and abiotic risks and losing competitiveness by not diversifying the use of rootstocks for the different ecosystems (Sampaio et al., 2016), such as the Coastal Tablelands region.

Thus, the objective of this study was to evaluate the effect of two rootstocks and two planting types on the growth, physiology, initial production, and root distribution of 'Pera' sweet orange at juvenile stage of development in the Coastal Tablelands region, state of Bahia, Brazil.

\section{MATERiAl AND Methods}

The experiment was conducted from 2017 to 2018 at the Lagoa do Coco Farm, in Rio Real, BA, Brazil ( $11^{\circ} 34^{\prime} 26^{\prime \prime}$ S, $37^{\circ} 52^{\prime} 39^{\prime \prime} \mathrm{W}$, and $170 \mathrm{~m}$ of altitude) in a commercial orchard with 3 years of formation, in an area of $16.128 \mathrm{~m}^{2}(128 \times 126$ $\mathrm{m}$ ) with 1,280 plants spaced $6.0 \times 2.0 \mathrm{~m}$ apart, under rainfed conditions.

The farm is in the Coastal Tablelands region. It presented Oxisols with cohesive soil horizons (Table 1) and plain relief; 'As', hot and wet climate, according to the Köppen classification; and mean annual temperature of $24.1^{\circ} \mathrm{C}$. The mean annual rainfall of the region is $1,100 \mathrm{~mm}$, with approximately $80 \%$ concentrated between April and September, in accordance with the climatic water balances of 2017 and 2018 estimated by the Thornthwaite \& Mather method (Rolim et al., 1998), based on rainfall data of the Lagoa do Coco Farm, and air temperature data of the nearest meteorological station (OMM: 83249, BDMEP - INMET; Alagoinhas, BA).

The rainfall during the experiment were $1,252 \mathrm{~mm}$ for 2017 , and $997 \mathrm{~mm}$ for 2018, which resulted in water deficit periods from January to April 2017, August 2017 to March 2018, and July to December 2018, with accumulated values of $419.6 \mathrm{~mm}$ for 2017, and $572.6 \mathrm{~mm}$ for 2018 .

The citrus plants were formed using orange scions of the cultivar 'Pera' sweet orange [Citrus sinensis (L.) Osbeck], CNPMF D-6 selection, combined with the rootstocks 'Santa Cruz Rangpur' lime (C. limonia Osbeck) and 'Sunki Tropical' mandarin [C. sunki (Hayata) hort. ex Tanaka], through grafting by budding (inverted $\mathrm{T}$ at $12 \mathrm{~cm}$ ). Both rootstocks were selected due to their tolerance to droughts. The first is the most used in the region and the second is recommended as an alternative for citriculture in the state of Bahia, Brazil (Cunha Sobrinho et al., 2013; Rodrigues et al., 2015; Vieira et al., 2016).

The propagative material (seeds, buds, and protected seedlings) was provided by the Citrus Breeding Program of Embrapa Cassava and Fruits.

The experiment was implemented in 2015, using a randomized block design in a split-plot arrangement, with eight repetitions, consisted of two scion-rootstock combinations ('Pera' sweet orange $\times$ 'Santa Cruz Rangpur' lime, and 'Pera' sweet orange $\times$ 'Sunki Tropical' mandarin) and two planting types (planting of protected seedlings - PPS, and planting of seeds in definitive place - PSD). Each block was composed of eight plots, and each plot was composed of five planting rows with four plants each. The six central plants were considered in the evaluations.

The sowing of the rootstocks was carried out in May 2014 for both planting types. The grafting of the rootstocks in the field and the planting of seedlings produced in the screened nursery were carried out after 14 months. Twenty-four plants were selected for evaluations of shoot growth, root architecture, and physiology in February 2017.

Shoot growth was evaluated six times from August 2017 to October 2018, considering the following measures: plant height expressed in meters, canopy diameters in the row (CDR), and cross-row directions (CDC), expressed in meters, and stem diameters at $0.05 \mathrm{~m}$ below and above the grafting point, expressed in $\mathrm{mm}$.

These data were used to calculate the vegetative vigor index (VVI; dimensionless), canopy cover area in the row (CCAR; $\%)$, canopy cover area between rows (CCAB; \%), and mean

Table 1. Sand, silt, and clay concentrations, textural class, density (SD), hydraulic conductivity ( $\left.\mathrm{K}_{0}\right)$, and soil mechanical resistance to penetration (SMRP) throughout the profile of an Oxisol. Lagoa do Coco Farm, BA, Brazil

\begin{tabular}{|c|c|c|c|c|c|c|c|}
\hline $\begin{array}{c}\text { Horizon/Depth } \\
\text { (m) }\end{array}$ & Sand & $\frac{\text { Silt }}{\left(\mathrm{g} \mathrm{kg}^{-1}\right)}$ & Clay & $\begin{array}{c}\text { Textural } \\
\text { class }\end{array}$ & $\begin{array}{c}\text { SD } \\
\left(\mathrm{kg} \mathrm{dm^{-3 } )}\right.\end{array}$ & $\begin{array}{c}\mathrm{K}_{0} \\
\left(\mathrm{~cm} \mathrm{~h}^{-1}\right)\end{array}$ & $\begin{array}{l}\text { SMRP } \\
\text { (MPa) }\end{array}$ \\
\hline $\mathrm{A} / 0.00-0.18$ & 746 & 58 & 196 & $\mathrm{SL}$ & 1.48 & 0.84 & 1.07 \\
\hline $\mathrm{AB} / 0.18-0.39$ & 726 & 72 & 202 & SCL & 1.61 & 0.47 & 2.74 \\
\hline $\mathrm{BA} / 0.39-0.68$ & 663 & 63 & 276 & $\mathrm{SCL}$ & 1.75 & 0.09 & 5.25 \\
\hline BW1/0.68-1.07 & 644 & 36 & 320 & $\mathrm{SCL}$ & 1.41 & & \\
\hline BW2/1.07-1.65+ & 624 & 60 & 316 & SCL & 1.50 & & \\
\hline
\end{tabular}

SL - Sandy-loam; SCL - Sandy-clay-loam. Source: Calfa (2010) 
canopy volume (MCV; $\left.\mathrm{m}^{3}\right)$, according to Portella et al. (2016), using Eqs. 1 to 4:

$$
\mathrm{CCAR}=\left(\frac{\mathrm{CDR}}{\mathrm{S}}\right) 100
$$

where CDR is the canopy diameter in row direction $(\mathrm{m})$ and $\mathrm{S}$ is the spacing used in the planting rows $(\mathrm{m})$;

$$
\mathrm{CCAB}=\left(\frac{\mathrm{CDC}}{\mathrm{S}}\right) 100
$$

where CDC is the canopy diameter in the cross-row direction $(\mathrm{m})$, and $\mathrm{S}$ is the spacing used between planting rows $(\mathrm{m})$;

$$
\mathrm{VVI}=\frac{[\mathrm{PH}+\mathrm{MCD}+(\mathrm{SDR} \cdot 100)]}{100}
$$

where $\mathrm{PH}$ is the plant height (m); MCD is the mean canopy diameter $(\mathrm{m})$, and SDR is the stem diameter of the rootstock $(\mathrm{mm})$;

$$
\mathrm{MCV}=\left(\frac{\pi}{6}\right) \cdot \mathrm{PH} \cdot \mathrm{CDR} \cdot \mathrm{CDC}
$$

where $\mathrm{PH}$ is the plant height $(\mathrm{m}), \mathrm{CDR}$ is the canopy diameter in row direction $(\mathrm{m})$, and $\mathrm{CDC}$ is the canopy diameter in the cross-row direction (m).

Soil and root samples were collected in October 2018 to evaluate root architecture, in seven sampling points distributed in two perpendicular axes, from the plant stems, namely: three points in the planting row $(0.50,1.00$, and $1.50 \mathrm{~m})$ and four points between planting rows $(0.50,1.00,1.50$, and $3.00 \mathrm{~m})$, in the $0-0.20,0.20-0.40,0.40-0.60,0.60-0.80,0.80-1.00$, and $1.00-1.20 \mathrm{~m}$ soil layers, except for the last point $(3.00 \mathrm{~m})$ in which samples were collected up to the depth of $0.40 \mathrm{~m}$, totaling 912 samples. The samples were collected using steel cylinders of $1.50 \mathrm{~m}$ length and $0.067 \mathrm{~m}$ internal diameter, which were inserted into the soil at each $0.20 \mathrm{~m}$ by sledgehammer strikes.

The roots were separated from the soil by immersion in water and sieved in a $1-\mathrm{mm}$ mesh sieve; they were stored in a $30 \%$ alcohol-water solution at temperature of 4 to $10^{\circ} \mathrm{C}$. The roots were scanned (Epson Expression 11000XL) with 400 dpi resolution, and the images were analyzed in the WinRhizo program (Regent Instruments Inc., Quebec, Canada) to assess the variables: total root length (TRL; $\mathrm{cm}$ ); mean root diameter (MRD; $\mathrm{mm}$ ); and root length within root diameter classes $(\mathrm{d} 1<0.5 ; 0.5<\mathrm{d} 2<1.0 ; 1.0$ $<\mathrm{d} 3<1.5 ; 1.5<\mathrm{d} 4<2.0 ; 2.0<\mathrm{d} 5<2.5 ; 2.5<\mathrm{d} 6<3.0 ; 3.0<\mathrm{d} 7<$ $3.5 ; 3.5<\mathrm{d} 8<4.0 ; 4.0<\mathrm{d} 9<4.5$; and $\mathrm{d} 10>4.5 \mathrm{~mm}$ ).

The samples were then dried in an oven at $60{ }^{\circ} \mathrm{C}$ until constant weight to assess their root dry weight (RDW; g); specific root length (SRL), obtained by the TRL to RDW ratio $\left(\mathrm{cm} \mathrm{g}^{-1}\right)$; and root length density (RLD; $\mathrm{cm} \mathrm{cm}^{-3}$ ), obtained by dividing the TRL by the soil volume collected $\left(\mathrm{cm}^{3}\right)$ of each sample.

The RLD, SLR, and RDW data were used to generate isoline maps, with the mean of each point sampled by treatment, using the Surfer 8 program.
Soil moisture was monitored by time domain reflectometry (TDR), with sensors distributed vertically $(0-0.20,0.20-0.40$, $0.40-0.70,0.70-1.10$, and $1.10-1.70 \mathrm{~m})$, at $0.5 \mathrm{~m}$ of the plant stem, perpendicularly to the planting row, at every $0.20 \mathrm{~m}$ of the soil surface.

Sixty TDR probes were installed, five per plant in 12 'Santa Cruz Rangpur' lime rootstock. The positioning of the sensors in the soil profile was established according to the horizons characterized by Calfa (2010) (Table 1). The measure device used for the readings was the TDR 100, which is manufactured by the Campbell Scientific company.

The TDR probes were made in the Laboratory of Irrigation and Drainage of the Embrapa Cassava and Fruits with the following specifications: three 0.10-meter stainless steel bars spaced $0.017 \mathrm{~m}$ apart, fixed to a polyester resin block with dimensions of $0.05 \times 0.045 \times 0.015 \mathrm{~m}$, connected to a coaxial cable of $50 \mathrm{ohms}$, of variable length $(1.25,1.50$, and $2.00 \mathrm{~m})$.

The soil resistance to mechanical penetration was measured using a Stolf penetrometer (STOLF et al., 1983) in August 2018 and February 2019, in 24 sampling points (three repetitions by treatment), at one meter from the plant, in the planting row, up to the depth of $0.60 \mathrm{~m}$. The results were transformed into $\mathrm{MPa}$ (unit of pressure) according to the equation described by Stolf (1991) and Stolf et al. (2014), in intervals of $0.10 \mathrm{~m}$ depth.

The data of each evaluation time were subjected to analysis of variance. The significant interactions were tested, and the means were compared by the Tukey's test at $\mathrm{p} \leq 0.05$.

\section{Results AND Discussion}

Plant height, stem diameters below and above the grafting point, vegetative vigor index, canopy cover area in the row and between rows, and mean canopy volume at 40 months of formation of the orchard were always higher for the 'Santa Cruz Rangpur' lime (SCRL) when compared to the 'Sunki Tropical' mandarin (STM) (Figure 1).

Considering the whole root system, the root lengths within the root diameter classes $(\mathrm{d} 1<0.5 ; 0.5<\mathrm{d} 2<1.0 ; 1.0<\mathrm{d} 3<$ $1.5 ; 1.5<\mathrm{d} 4<2.0 ; 2.0<\mathrm{d} 5<2.5 ; 2.5<\mathrm{d} 6<3.0 ; 3.0<\mathrm{d} 7<3.5$; $3.5<\mathrm{d} 8<4.0 ; 4.0<\mathrm{d} 9<4.5$; and $\mathrm{d} 10>4.5 \mathrm{~mm}$ ) were higher for the planting of protected seedlings (PPS) when compared to the planting of seeds in definitive place (PSD). Both crops presented predominance of thin roots $(<2 \mathrm{~mm})$ (Figure 2$)$. The rootstock had no effect on the root diameter classes.

The planting type had significant effect $(\mathrm{p} \leq 0.05)$ on total root length (TRL), root length density (RLD), mean root diameter (MRD) and root diameter classes $(<2$ and $>2 \mathrm{~mm})$ in the longitudinal profile to the plant row, with higher values for PPS, whereas no isolate effects or interaction between the factors studied on these variables were found for the orthogonal profile to the plant row (Figure 3).

The diameter class distribution in the longitudinal profile showed that the difference between planting types was significant for roots with diameters lower than $2 \mathrm{~mm}$, in the $0-0.20 \mathrm{~m}$ and $0.20-0.40 \mathrm{~m}$ layers, with higher values for PPS (Figure 3C). This same trend was found for roots with diameters higher than $2 \mathrm{~mm}$ in the soil 0-0.20 m layer (Figure $3 \mathrm{D})$. This denotes the importance of a quality seedling planting 

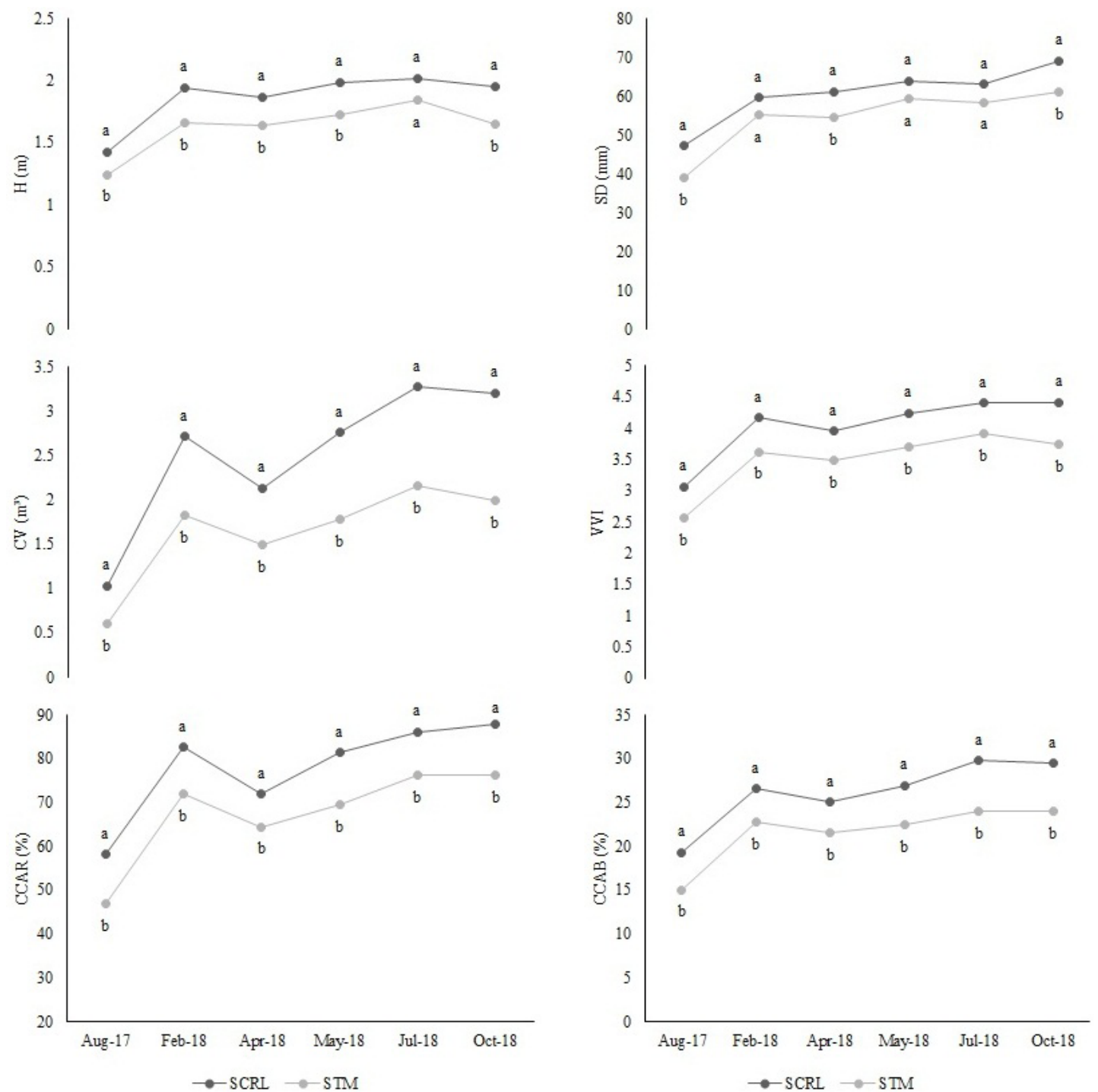

Figure 1. Plant height $(\mathrm{H})$, stem diameter below the grafting point (SD), canopy volume (CV), vegetative vigor index (VVI), canopy cover area in the row (CCAR) and between rows (CCAB) of 'Santa Cruz Rangpur' lime (SCRL) (C. limonia Osbeck) and 'Sunki Tropical' mandarin (STM) [C. sunki (Hayata) hort. ex Tanaka] over the evaluation times

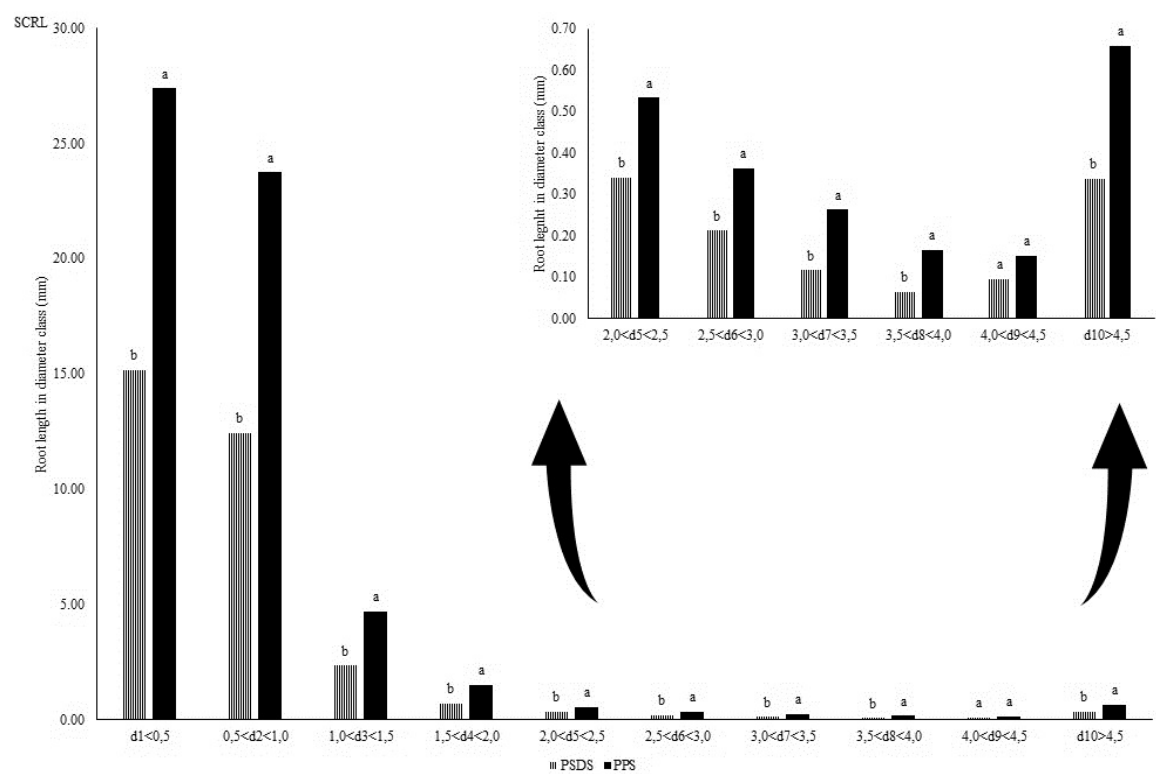

Classes higher than $2 \mathrm{~mm}$ are detailed in the upper corner

Figure 2. Root length within root diameter classes $(\mathrm{d} 1<0.5 ; 0.5<\mathrm{d} 2<1.0 ; 1.0<\mathrm{d} 3<1.5 ; 1.5<\mathrm{d} 4<2.0 ; 2.0<\mathrm{d} 5<2.5$; $2.5<\mathrm{d} 6<3.0 ; 3.0<\mathrm{d} 7<3.5 ; 3.5<\mathrm{d} 8<4.0 ; 4.0<\mathrm{d} 9<4.5$; and $\mathrm{d} 10>4.5 \mathrm{~mm}$ ) of 'Pera' sweet orange trees [C. sinensis (L.) Osbeck] as a function of planting types (planting of protected seedlings - PPS, and planting of seeds in definitive place - PSD) 

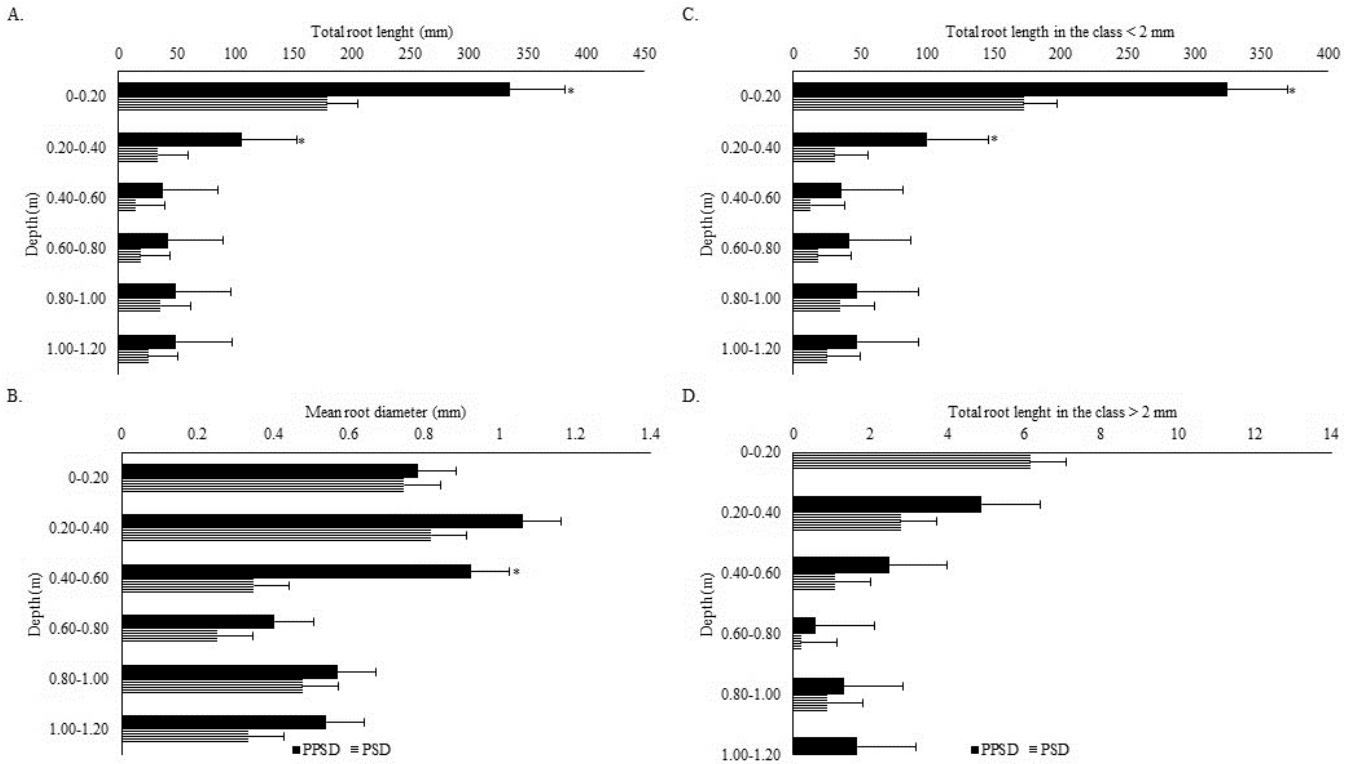

* - Significantly different by Tukey's test $(\mathrm{p} \leq 0.05)$

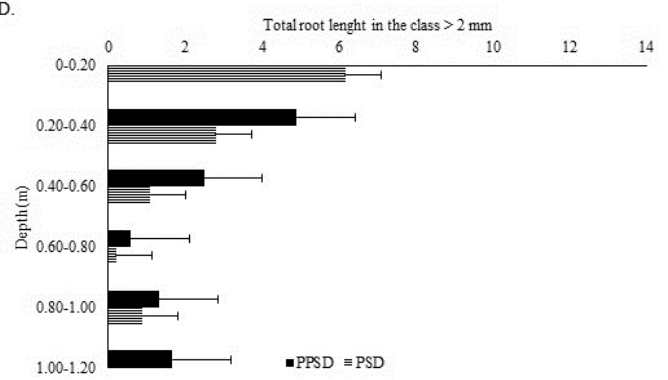

Figure 3. Total root length (A), mean root diameter (B), total root length in the diameter class $<2 \mathrm{~mm}(\mathrm{C})$ and $>2 \mathrm{~mm}(\mathrm{D})$, in the longitudinal profile to plant rows of 'Pera' sweet orange trees [C. sinensis (L.) Osbeck] under seed planting (PSD) and seedling planting (PPS)

(PPS) for the root system formation of citrus plant by its better distribution throughout the soil profile, and formation of roots with diameters that perform different functions and are essential to the plant development.
The rooting in the longitudinal profile was better than that in the orthogonal profile for all root variables analyzed (Figure 4), regardless of the planting type and rootstock used, except root dry weight (RDW), which presented no significant difference.
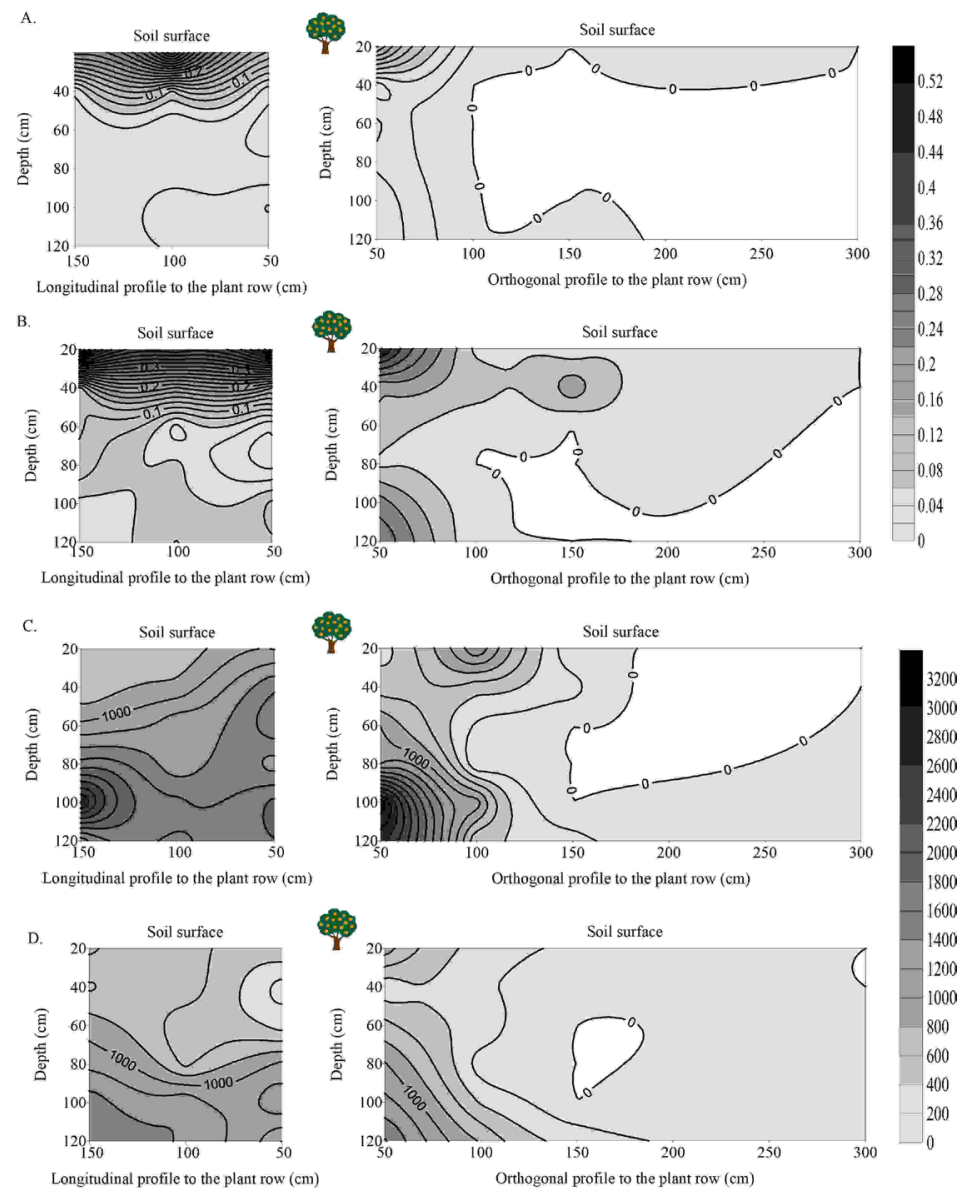

Figure 4. Root length density (RLD; $\mathrm{cm} \mathrm{cm}^{-3}$ ), related to seed planting (A) and seedling planting (B); specific root length $\left(\mathrm{SRL} ; \mathrm{cm} \mathrm{g}^{-1}\right)$ related to the rootstocks 'Santa Cruz Rangpur' lime (C. limonia Osbeck) (C) and 'Sunki Tropical' mandarin [C. sunki (Hayata) hort. ex Tanaka] (D) in the longitudinal and orthogonal profiles to the plant row of 'Pera' sweet orange [C. sinensis (L.) Osbeck] trees 
RLD, TRL, and diameter classes $(<2$ and $>2 \mathrm{~mm})$ were significantly different in deeper layers in the longitudinal and orthogonal profiles, with higher incidence in the 0-0.20 m layer, and in lower horizontal distances from the plant (Figures $4 \mathrm{~A}$ and $\mathrm{B}$ ). The highest MRD were found in the 0.20-0.40 m layer (Figure $3 \mathrm{~B}$ ) due to the contribution of thicker roots (Figure 3D). Citrus roots were not found at distances longer that three meters between planting rows (Figure 4).

PPS had higher RLD than PSD up to $0.40 \mathrm{~m}$ depth, in the longitudinal profile (Figures $4 \mathrm{~A}$ and $\mathrm{B}$ ). The orthogonal profile presented higher root concentration near the plant $(0.50 \mathrm{~m})$, in the $0-0.20 \mathrm{~m}$ layer. TRL showed similar response to RLD, since these variables are correlated.

The rootstocks had significant effect $(\mathrm{p} \leq 0.05)$ on specific root length (SRL), with higher results for the 'Santa Cruz Rangpur' lime (SCRL), regardless of the position evaluated (Figures $4 \mathrm{C}$ and D). The interaction between the factors was not significant for SRL in the orthogonal and longitudinal profiles.

The management practices adopted did not significantly change the root dry weight (RDW) in the planting row and between planting rows (Figure 5). The values were, in general, higher in surface layers because of the high root concentration (Figures 3 and 4).

Higher concentrations of roots (RLD, TRL, diameter classes, and SRL) were found for the longitudinal profile, when compared to the orthogonal profile. This was probably due to the contribution of the root system of both rootstocks, because of the denser planting spacing, which has been a tendency for citriculture (Azevedo et al., 2015; Ramos et al., 2015). In addition, the area was more shaded, without machinery traffic and soil turning, with higher moisture (Souza et al., 2007) due to the low soil water evaporation potential, and had lower weed competition and higher soil fertilizer concentrations, contributing to a higher root concentration under the canopy projection.

Lower values of soil water content were observed in superficial layer $(0-0.40 \mathrm{~m})$ (Figures $6 \mathrm{~A}$ and $\mathrm{B})$, which also had higher root concentration (Figures 3 and 4 ). This is a response to physical barriers generated by cohesive horizons (Table 1), which increase soil mechanical resistance to critical levels for root expansion (Figure 6), resulting in poor oxygenation and in low water availability to plants (Cintra, 2011; Tracy et al., 2011, Jin et al., 2017).

Higher values of soil water content were associated to plants sowing in definitive place (PSD) than those from protected seedlings (PPS), indicating higher water extraction in the PSS treatment, usually in periods with higher soil water availability (Figure 6A). Soil mechanical resistance to penetration (SMRP) was significantly affected $(\mathrm{p} \leq 0.05)$ by rootstock type (Figures $6 \mathrm{E}$ and F), with higher SMRP throughout the soil profile for the 'Santa Cruz Rangpur' lime (Figure 6E); it was probably due to the higher soil drying for this rootstock, due to its higher water extraction.

The roots were concentrated at a horizontal distance up to $1.50 \mathrm{~m}$ from the plant trunk, in the soil first $0.40 \mathrm{~m} \mathrm{depth}$ ( $64 \%$ of the root system), with $50 \%$ in the first $0.20 \mathrm{~m}$ depth, soil layer associated with higher water extractions over the evaluated period (Figures 6A and B).

The citrus roots system concentrated in the soil surface layers were also found in other studies, even in conditions with soil without physical barriers (Alves Júnior et al., 2012; Zaccheo et al., 2012). According to Santana et al. (2006), root concentration in surface soil horizons is associated to their higher biological activity and water and nutrients availability.

Gao et al. (2016) reported that root growth is inhibited in soils with SMRP above of $2.5 \mathrm{MPa}$, and the increases in SMRP in deeper layers are usually enough to make deep roots to stretch into existing pores network; this may have had happened in the present study due to the SMRP above 2.5 $\mathrm{MPa}$ in soil depths higher than $0.20 \mathrm{~m}$ (Table 1, Figures $6 \mathrm{C}, \mathrm{D}, \mathrm{E}$ and F).

According to Clark et al. (2003), the capacity of roots to penetrate soils with mechanical barriers is related to differences in root diameters. The results of the present study show the effect of subsurface cohesive horizons, between 0.18-0.68 m (Table 1), with thicker roots $(>2 \mathrm{~mm})$, structural roots, and predominance of thinner roots $(<2 \mathrm{~mm})$ above them (Figures $3 \mathrm{C}$ and $\mathrm{D}$ ), which contribute to maintain the plant turgidity (Santos et al., 2005; Rewald et al., 2011) and, consequently, to physiological responses of tolerance to droughts and plant vigor.

The PSD practice for citrus supposes to result in a higher root deepening because the original architecture of the root system remains intact (Rezende, 2013; Rezende et al., 2015). However, there was no difference in root deepening system between planting types as also found in field conditions by Oliveira et al. (2018) in a greenhouse study, in which the PPS of SCRL was correlated to higher root and shoot vigor, despite possible benefits of not cutting the pivoting root in the direct sowing.

The characteristics of each rootstock affected the vegetative vigor and SRL. Plants grafted on SCRL were more
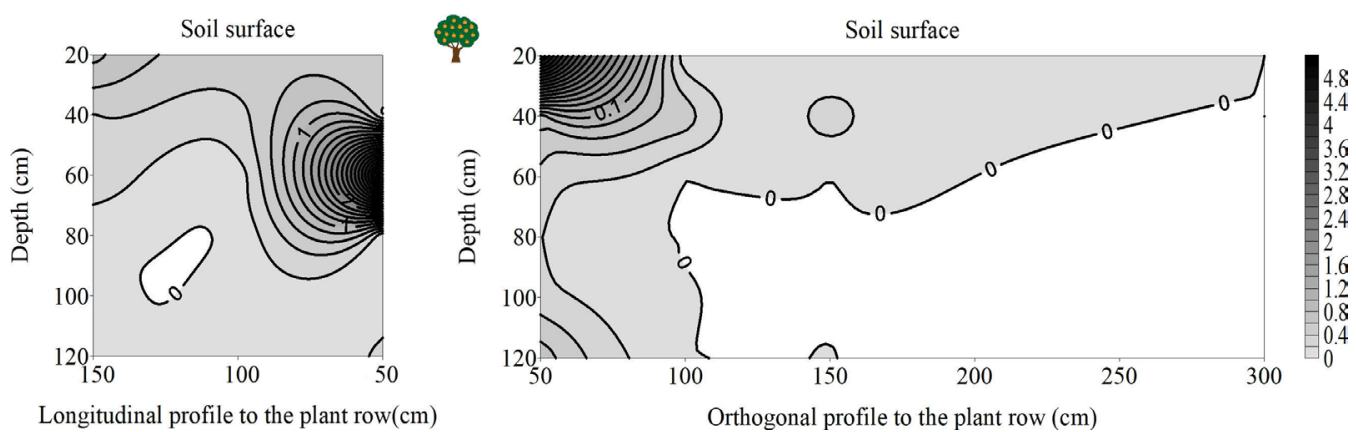

Figure 5. Root dry weight (RDW; g) distribution over the longitudinal and orthogonal profiles to the plant row of 'Pera' sweet orange [C. sinensis (L.) Osbeck] trees 
A.
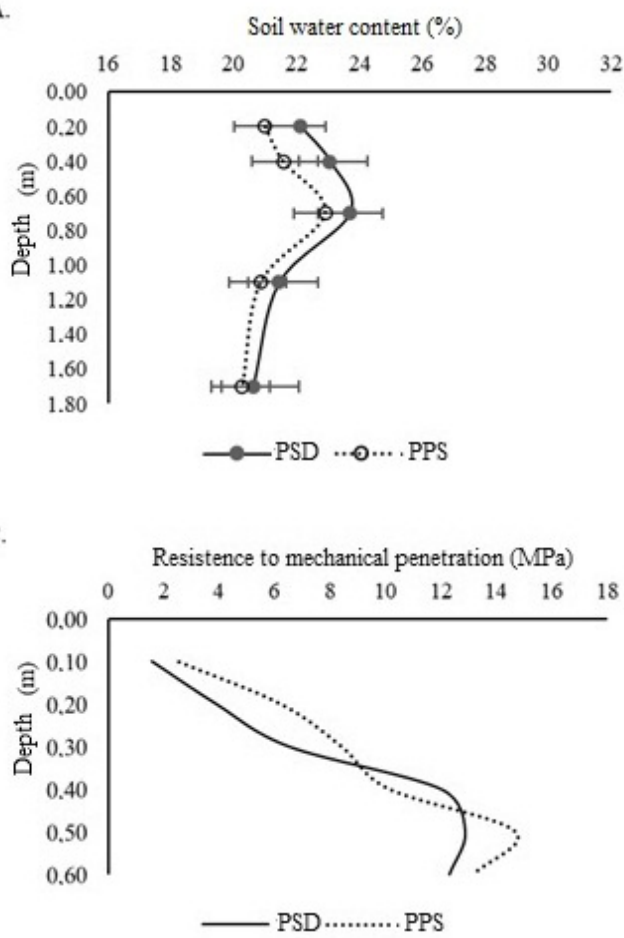

E.

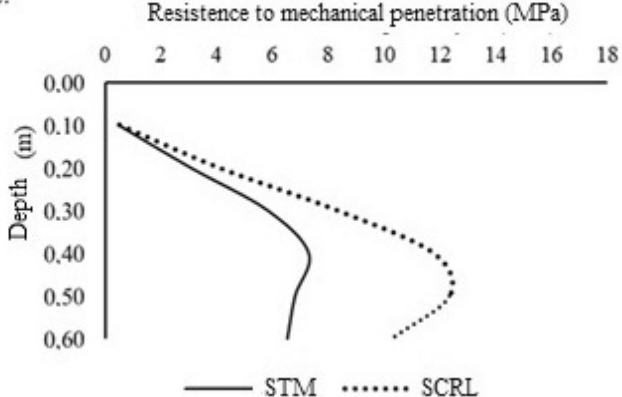

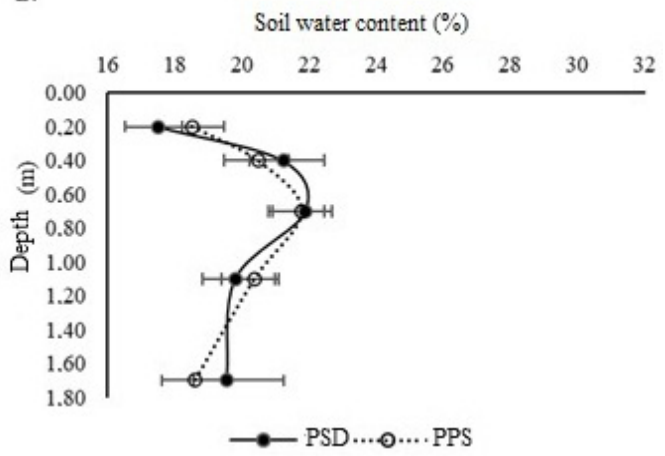

D.

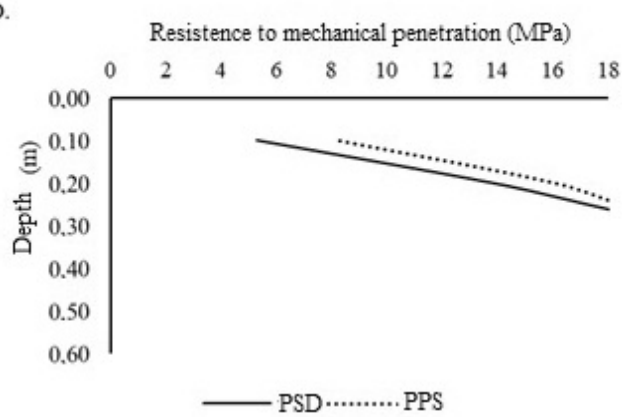

F.

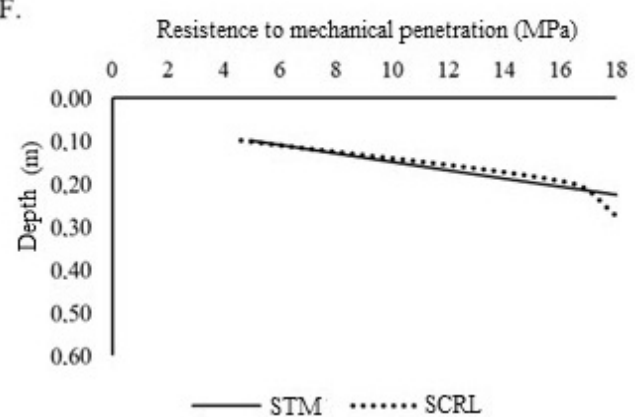

Figure 6. Soil water content throughout the profile as a function of planting types (seedling - PPS, and seeds - PSD) in August 2018 (A) and February 2019 (B); and soil resistance to mechanical penetration as a function of planting types (PPS and PSD), and rootstocks \{'Santa Cruz Rangpur' lime - SCRL (C. limonia Osbeck), and 'Sunki Tropical' mandarin - STM [C. sunki (Hayata) hort. ex Tanaka]\}, in August 2018 (C and E) and February 2019 (D and F), respectively

vigorous (Figure 4C), which may indicate higher water extraction capacity from the soil for this rootstock due to the higher SRL when compared to STT. It is connected to greater amounts of thin roots, higher root hydraulic conductivity, and higher thin root proliferation rates of citrus rootstocks (Eissentat, 1991; Eissentat \& Achor, 1999; Rewald et al., 2011).

According to Coelho et al. (2008), water extractions by fruit trees occur in points with higher roots concentration and soil moisture; and higher root system expansion is expected for plants with higher vigor, in large distances from the plants and in deep soil layers. This allowed SCRL to explore a higher soil volume per unit of metabolic investment in their tissues, being more efficient in water and nutrient absorption per unit of carbon (Nippert \& Holdo, 2015; Gonçalves et al., 2016; Sampaio et al., 2016; Santos et al., 2017).

Vieira et al. (2016) found that the 'Santa Cruz Rangpur' lime tree has a strategy to prevent dehydration and keep its growth under water deficiency conditions, whereas the 'Sunki Maravilha' mandarin tangerine strategy for tolerance to droughts is focused on the plant survival. These strategies can explain the higher vegetative vigor of SCRL in the evaluations (Figure 1) and its precocity in fruits production compared to STT, whose mean yield in 2018 reached $5.04 \mathrm{Mg} \mathrm{ha}^{-1}$ for SCRL and $0.79 \mathrm{Mg} \mathrm{ha}^{-1}$ for STT.

This present study revealed that soil structure affect root growth and, consequently, the crop performance; that the planting of quality seedlings is the most recommended for the management of orchards in the Coastal Tablelands of Brazil; and that 'Santa Cruz Rangpur' lime rootstock are a more adaptive choice for citriculture in this region.

\section{Conclusions}

1. The planting of seedlings produced in screened nursery increase total root length, root length density, mean root diameter, and diameter classes, and result in higher water extraction from the soil than the planting of seeds.

2. The roots were concentrated in short horizontal distances from the plant and in surface soil layers, up to $0.40 \mathrm{~m}$ depth, 
regardless of the management practices adopted, as well as the soil moisture.

\section{ACKNOWLEDgements}

The authors thank the Lagoa do Coco Farm; the Brazilian Agricultural Research Corporation (Embrapa Mandioca e Fruticultura - CNPMF); the Fundação de Amparo à Pesquisa do Estado da Bahia (FAPESB) for granting a doctoral scholarship for the author T. N. M.; and the Conselho Nacional de Desenvolvimento Científico e Tecnológico $(\mathrm{CNPq})$ for the support to the author M. A. C. F. (312796/2018-8).

\section{Literature Cited}

Alves Júnior, J.; Bandaranayake, W.; Parsons, L. R.; Evangelista, A. W. P. Citrus root distribution under water stress grown in sandy soil of central Florida. Engenharia Agrícola, v.32, p.1109-1115, 2012. https://doi.org/10.1590/S0100-69162012000600012

Azevedo, F. A.; Pacheco, C. A.; Schinor, E. H.; Carvalho, S. A.; Conceição, P. M. Produtividade de laranjeira Folha Murcha enxertada em limoeiro Cravo sob adensamento de plantio. Bragantia, v.74, p.184-188, 2015. https://doi.org/10.1590/16784499.0374

Calfa, C. H. Subsolagem em solo coeso de Tabuleiro Costeiro e desenvolvimento da lima da 'Pérsia' com porta-enxerto semeado no local definitivo do pomar. Salvador: UFBA, 2010. 110p. Tese Dourado

Cintra, F. L. D. Manejo de solos coesos dos tabuleiros costeiros. In: Tofanelli, M. B. D.; Silva, T. O. (eds.) Manejo ecológico e conservação dos solos e da água no estado de Sergipe. São Cristóvão: UFS, 2011. Cap.5, p.205-226.

Clark, L. J.; Whalley, W. R.; Barraclough, P. B. How do roots penetrate strong soil? Plant and Soil, v.255, p.93-104, 2003. https:/doi. org/10.1023/A:1026140122848

Coelho, E. F.; Simões, W. L.; Carvalho, J. E. B.; Coelho Filho, M. A. Distribuição de raízes e extração de água do solo em fruteiras tropicais sob irrigação. 1.ed. Cruz das Almas: Embrapa Mandioca e Fruticultura Tropical, 2008. 80p.

Cunha Sobrinho, A. P.; Passos, O. S; Soares Filho, W. S. Cultivares porta-enxerto. In: Cunha Sobrinho, A. P.; Magalhães, A. F. J.; Souza, A. S, Passos; O. S, Soares Filho, W. S. (eds). Cultura dos citros. Brasília, DF: Embrapa, 2013, Cap.9, p.233-271.

Eissenstat, D. On the relationship between specific root length and the rate of root proliferation: A field study using citrus rootstocks. New Phytologist. v.118, p.63-68, 1991. https://doi. org/10.1111/j.1469-8137.1991.tb00565.x

Eissenstat, D.; Achor, D. Anatomical characteristics of roots of citrus rootstocks that vary in specific root length. The New Phytologist, v.141, p.309-321, 1999. https://doi.org/10.1046/ j.1469-8137.1999.00342.x

Gao, W.; Hodgkinson, L.; Jin, K.; Watts, C. W.; Ashton, R. W.; Shen, J.; Ren, T.; Dodd, I. C.; Binley, A. M.; Phillips, A. L.; Hedden, P.; Hawkesford, M. J.; Whalley, W. R. Deep roots and soil structure. Plant, Cell \& Environment, v.39, p.1662-1668, 2016. https://doi. org/10.1111/pce.12684
Gonçalves, L. P.; Alves, T. F. O.; Martins, C. P. S.; Sousa, A. O.; Santos, I. C.; Pirovani, C. P.; Almeida, A. F.; Coelho Filho, M. A.; Gesteira, A. S.; Soares Filho, W. S.; Girardi, E. A.; Costa, M. G. C. Rootstock-induced physiological and biochemical mechanisms of drought tolerance in sweet orange. Acta Physiologiae Plantarum, v.38, p.1-12, 2016. https://doi.org/10.1007/s11738016-2198-3

IBGE - Instituto Brasileiro de Geografia Estatística. Levantamento sistemático da produção agrícola: Produção agrícola municipal, 2017. Available on: <http://www.cnpmf.embrapa.br/Base_de_ Dados/index_pdf/dados/brasil/laranja/b1_laranja.pdf $>$. Accessed on: Jan. 2019.

Jin, K.; White, P. J.; Whalley, W. R.; Shen, J.; Shi, L. Shaping an optimal soil by root-soil interaction. Trends in Plant Science, v.22, p.823-829, 2017. https://doi.org/10.1016/j. tplants.2017.07.008

Nippert, J. B.; Holdo, R. M. Challenging the maximum rooting depth paradigm in grasslands and savanas. Functional Ecology, v.29, p.739-745, 2015. https://doi.org/10.1111/1365-2435.12390

Oliveira, L. B.; Coelho Filho, M. A.; Arriero, S. S.; Gomes Júnior, F. A.; Cova, A. M. W.; Soares Filho, W. S.; Gesteira, A. S. Ability of citrus root system to overcome a strong wax layer. Journal of Agricultural Science, v.10, p.213-223, 2018. https://doi. org/10.5539/jas.v10n10p213

Portella, C. R.; Marinho, C. S.; Amaral, B. D.; Carvalho, W. S. G.; Campos, G. S.; Silva, M. P. S.; Sousa, M. C. Desempenho de cultivares de citros enxertadas sobre o trifoliateiro 'Flying Dragon' e limoeiro 'Cravo' em fase de formação do pomar. Bragantia, v.75, p.70-75, 2016. https://doi.org/10.1590/1678-4499.267

Ramos, Y. C.; Stuchi, E. S.; Girardi, E. A.; Leão, H. C.; Gesteira, A. S.; Passos, O. S.; Soares Filho, W. S. Dwarfing rootstocks for Valencia sweet orange. Acta Horticulturae, v.42, p.351-354, 2015. https:// doi.org/10.17660/ActaHortic.2015.1065.42

Rewald, B.; Ephrath, J. E.; Rachmilevitch. A root is a root is a root? Water uptake rates of citrus root orders. Plant, Cell \& Environment, v.34, p.33-42, 2011. https://doi.org/10.1111/j.13653040.2010.02223.x

Rezende, J. O. O plantio direto dos citros: Mito ou realidade? Revista Bahia Agrícola, v.9, p.72-85, 2013.

Rezende, J. O.; Shibata, R. T.; Souza, L. S. Justificativa e recomendações técnicas para o "plantio direto" dos citros nos Tabuleiros Costeiros: ênfase na citricultura dos Estados da Bahia e Sergipe. 1.ed. Cruz das Almas: UFRB, 2015. 240p.

Rodrigues, M. J. S.; Ledo, C. A. S.; Girardi, E. A.; Almeida, L. A. H.; Soares Filho, W.S. Caracterização de frutos e propagação de porta-enxertos híbridos de citros em ambiente protegido. Revista Brasileira de Fruticultura, v.37, p.457-470, 2015. https://doi. org/10.1590/0100-2945-068/14

Rolim, G. S.; Sentelhas, P. C.; Barbieri, V. Planilhas no ambiente EXCEL TM para os cálculos de balanços hídricos: Normal, sequencial, de cultura e de produtividade real e potencial. Revista Brasileira de Agrometeorologia, v.6, p.133-137, 1998.

Sampaio, A. H. R.; Coelho Filho, M. A.; Souza, L. D.; Brito, R. F.; Silva, R. O. Yield and quality of 'pera' sweet orange grafted on different rootstocks under rainfed conditions. Revista Brasileira de Fruticultura, v.38, p.771-779, 2016. https://doi.org/10.1590/010029452016770 
Santana, M. B.; Souza, L. S.; Souza, L. D.; Fontes, L. E. F. Atributos físicos do solo e distribuição do sistema radicular de citros como indicadores de horizontes coesos em dois solos de Tabuleiros Costeiros do Estado da Bahia. Revista Brasileira de Ciência do Solo, v.30, p.1-12, 2006. https://doi.org/10.1590/S0100-06832006000100001

Santos, D. B.; Coelho, E. F.; Azevedo, C. A. V. Absorção de água pelas raízes do limoeiro sob distintas frequências de irrigação. Revista Brasileira de Engenharia Agrícola e Ambiental, v.9, p.327-333, 2005. https://doi.org/10.1590/S1415-43662005000300006

Santos, I. C.; Almeida, A. F.; Pirovani, C. P.; Costa, M. G. C.; Silva, M. F. G. F.; Bellete, B. S.; Freschi, L.; Soares Filho, W. S; Coelho Filho, M. A.; Gesteira, A. S. Differential accumulation of flavonoids and phytohormones resulting from the canopy/rootstock interaction of citrus plants subjected to dehydration/rehydration. Plant Physiology and Biochemistry, v.119, p.147-158, 2017. https:// doi.org/10.1016/j.plaphy.2017.08.019

Souza, L. D.; Souza, L. S.; Ledo, C. A. S. Sistema radicular dos citros em Neossolo Quartzarênico dos Tabuleiros Costeiros sob irrigação e sequeiro. Pesquisa Agropecuária Brasileira, v.42, p.1373-1381, 2007. https://doi.org/10.1590/S0100-204X2007001000002

Stolf, R. Teoria e teste experimental de fórmulas de transformação dos dados de penetrômetro de impacto em resistência do solo. Revista Brasileira de Ciência do Solo, v.15, p.229-235, 1991.
Stolf, R.; Fernandes, J.; Furlani Neto, V. L. Penetrômetro de impacto modelo IAA/Planalsucar-Stolf: recomendação para seu uso. STAB, 1:18-23, 1983. [(Reeditado: Piracicaba, IAA/PLANALSUCAR, 1983. 9p. (Série Penetrômetro de Impacto. Boletim, 1)]

Stolf, R; Murakami, J. H.; Brugnaro, C.; Silva, L.G. S.; Silva, L.C.F. da; Margarido, L. A. C. Penetrômetro de impacto stolf - programa computacional de dados em EXCEL-VBA. Revista Brasileira de Ciência do Solo. v.38, n.3, p.774-782, 2014. https://doi. org/10.1590/S0100-06832014000300009

Tracy, S. R.; Black, C.R.; Roberts, J. A.; Mooney, S. J. Soil compaction: a review of past and present techniques for investigating effects on root growth. Journal of the Science of Food and Agriculture. v.91, p.1528-1537, 2011. https://doi.org/10.1002/jsfa.4424

Vieira, D. D. S. S.; Freschi, L.; Almeida, L. A. H.; Moraes, D. H. S.; Neves, D. M.; Santos, L. M.; Gesteira, A. S. Survival strategies of citrus rootstocks subjected to drought. Scientific Reports, v.6, p.1-12, 2016. https://doi.org/10.1038/srep38775

Zaccheo, P. V. C.; Neves, C. S. V. J.; Srenzel, N. M. C.; Okumura, R. S. Distribuição do sistema radicular de porta-enxertos sob laranjeira 'Folha Murcha' em clima subtropical. Semina: Ciências Agrárias, v.33, p.921-930, 2012. https://doi.org/10.5433/1679$0359.2012 v 33 n 3 p 921$ 